\title{
The Use of Android-Based PhET Simulation as an Effort to Improve Students' Critical Thinking Skills during the Covid-19 Pandemic
}

\author{
https://doi.org/10.3991/ijim.v14i19.15701 \\ Faiz Hasyim \\ Universitas Negeri Surabaya, Surabaya, Indonesia \\ STKIP Al Hikmah Surabaya, Surabaya, Indonesia \\ Tjipto Prastowo, Budi Jatmiko (ه) \\ Universitas Negeri Surabaya, Surabaya, Indonesia \\ budijatmiko@unesa.ac.id
}

\begin{abstract}
Covid-19 spurs teachers to carry out online learning. This study aims to describe the improvement of students' critical thinking skills through online learning assisted by Android-based PhET Simulation. This research is a Quasi Experiment using one group pre-test and post-test design which involves 27 students from VIII class who take science program in MTs Alif Laam Miim Surabaya (the level of education or school which is the same as Junior High School), Indonesia. The research instrument used in this study is a critical thinking skill test. Before and after the learning activities, the students were given a pre-test and post-test. The data collection is analyzed using descriptive quantitative research. The Results of the study show that there is an increase in the students' critical thinking skills which is statistically significant with average of $\mathrm{N}$ gain for about .57, categorized as medium. The highest $\mathrm{N}$-gain is achieved in the indicator "interpretation", which is for about .83 and categorized as high. While for the lowest comes from the indicator "analysis", which is equal to .39, categorized as medium. It can be concluded that online science learning assisted by PhET Simulation can improve the critical thinking skills of students in MTs.
\end{abstract}

Keywords_-PhET Simulation, Critical Thinking Skills, Covid-19

\section{Introduction}

Covid-19 gives important lessons for educators on how learning continues even with an online system. Starting emerged from Wuhan China at the end of the year 2019; World Health Organization (WHO) has set this phenomenon as a pandemic [1]. However, under any circumstances, learning process must continue. In facing the era of globalization, the skills needed in this century are:

1. Analytical skills which include critical thinking skills, problem solving, decision making, research and investigation 
2. Interpersonal skills which include communication, collaboration, leadership and responsibility skills

3. Ability to take initiative

4. Processing of information focusing on information literacy, digital literacy, Information Communication and Technological (ICT) Literacy

5. Skills for creativity, adaptive learning, and flexibility [2]

Moreover, the use of technology has become one of the main trends in education by replacing conventional textbooks with smart phone technology to support learning [3]. The use of technology in learning had been carried out by Papadakis [4] by investigating the use of a programming application (Scratch) which is very useful for prospective teachers. The results of the research proved that the use of Scratch is able to arouse students' interest and familiarize them with the basics of programming. Papadakis' research $[5,6]$ showed satisfying results through semi-structured interviews. By involving five students as part of the activities program of the school, the evaluation of the implementation showed satisfying results. Through their engagement, students understood the basic concepts of programming and technology when they were engaged in learning. The study of the prospective teacher in one of the departments of education of children in early age, University of Education in Greece also supported the previous research. Self-efficacy of kindergarten prospective teachers in thinking computing experienced a significant increase after the use of ScratchJr [7]. Those prospective teachers were also willing to use ScratchJr in science learning, since it is able to make science learning more interactive $[7,8]$.

Skills that continue to be trained will become a habit. Just like the critical thinking skills, when it is continuously trained in science learning, it is expected to:

1. Help students in making decisions and solving problems

2. Apply knowledge, experience and skills of critical thinking

3. Generate ideas or creative and innovative works

4. Overcome hasty and narrow-minded

5. Being open in accepting and giving opinions, making judgments based on reasons, and daring to argue critically and logically [9]

In learning science, students who have higher critical thinking skills will also get higher learning result compared with the students who have lower critical thinking skills. It happens because critical thinking consists of abilities, knowledge, values, attitudes, skills, and process [10]. Critical thinking includes self-organizing and assessments that produce interpretation, analysis, evaluation, and inference, accompanied by explanations of evidence, conceptual, methodological, critical, or contextual considerations on which the assessment is based. Therefore, practicing critical thinking skills in science learning is undoubtedly necessary.

One of the aspects of the intelligence of the people of Indonesia success is still at the level of medium and low [11]. It is supported by the results of PISA in the year of 2018, which stated that the average score of students' science literacy in Indonesia is 396 which are on level one. At this level, students can only solve simple problems. While to think analytically, critically and be able to solve problems require the skills to think 
on level three and four that is able to think more complex [12]. Therefore, the achievement of students' science literacy in Indonesia in the year 2018 was at rank 70 out of 78 countries, which was lower than scores in PISA 2015 [13]. It showed that students in Indonesia are on the level of attainment of skills to think that is still low. This phenomenon is also supported by the learning process which practically has conducted using the teacher centered learning model. This model is still teacher-centered, so students tend to be inactive and have not shown good higher-order thinking processes [10]. Based on this phenomenon, efforts to practice critical thinking skills through science learning are needed thus students' critical thinking skills can improve.

The use of Physics Education Technology (PhET) as one of media is an alternative science learning strategy to make students more active in learning. A lot of previous research has not revealed students' critical thinking skills in MTs (level of education or school-level which is the same as Junior High School) yet. One of the examples of the research is that PhET Simulation can enhance the learning process [14], the motivation to learn and understanding of conceptual problems [15], scientific investigation [16], and problem solving $[17,18]$. The use of technology in learning is one of efforts to improve students' critical thinking through information technology approach [19].

Based on the background of the problems that have been explained above, this study aims to determine whether the use of Android-Based PhET Simulation in online science learning can help students of MTs in achieving higher critical thinking skills [20, 21]. In other words, this study aims to describe the improvement of students' critical thinking skills through online learning assisted by Android-based PhET Simulation.

\section{Literature Review}

\subsection{Critical thinking skills}

Students' thinking abilities or skills should be trained. Skills that continue to be trained will become a habit of the students, thus the skill can evolve [5]. Likewise, students' critical thinking skills needs to be trained well so that students are accustomed to think critically, one of which is by learning that supports the critical thinking process. Critical thinking skills are defined as skills to identify source of information, analyze credibility, and draw conclusions based on the data obtained [22]. Critical thinking is a description of a person's ability to control thoughts [20]. Facione (2015) formulated several indicators of critical thinking skills, they are:

1. Interpretation

2. Analysis

3. Evaluation

4. Inference

5. Explanation

6. Self-regulation [23].

Thus, it can be concluded that the skill to think critically is a skill to think which involves a high cognitive process consisting of: the analysis, synthesis, and evaluation 
through several activities such as analyzing the facts, delivering reasons, evaluating, making conclusions, and giving scientific explanation.

\subsection{PhET simulation}

$\mathrm{PhET}$ is a simulation that is created by University of Colorado that contains simulation of physics, biology, and chemistry learning for the benefit of teaching which can be accessed freely through https://phet.colorado.edu/ [24]. In addition, PhET Simulation also can be accessed via Android Google Play Store to make it easier and more practical to use. PhET Simulation emphasizes the relationship between the phenomenon of real life with the knowledge that underlies, supports interactive and constructivist approach, gives feedback, and provides a creative workplace [25].

\subsection{Stages of science learning using guided inquiry model assisted by PhET simulation}

Science learning using the guided inquiry model assisted by PhET Simulation consists of 5 (five) phases, namely:

1. Identification and determination of the scope of the problem

2. Planning and predicting results

3. Investigation and data collection

4. Data interpretation and developing conclusion

5. Performing reflection

In more detail, the five phases of science learning using the guided inquiry model assisted by PhET Simulation can be explained as follows.

Phase 1: Identification and determination of the scope of the problem. This phase is the stage of development of the concept. It connects phenomenon with what students have known and motivate them to ask questions in line with the phenomenon. The aim of the teacher to ask the questions is to attract the attention of students in the topic and conduct exploration of the students' foreknowledge.

Phase 2: Planning and predicting results. In this phase, after the students have explored ideas through experience, students formulate questions and make a plan to investigate their questions. Furthermore, the students will also predict and think of the results. It takes time and practice before the students learn how to formulate questions. The teacher gives an example of how to ask questions that can be investigated and discards students' questions that cannot be investigated.

Phase 3: Investigation and data collection. In this phase, students are involved in investigation and collect data using the help of PhET Simulation. It is important to give enough time to the students to finish their investigation.

Phase 4: Data interpretation and developing conclusion. In this phase, the students compile arguments to support the data and test the hypotheses. Students make generalization relationships to develop conclusion. In other words, students analyze data to 
make a conclusion that can answer the problem presented. Furthermore, students communicate their findings (presentation) in various ways.

Phase 5: Perform reflection. In this phase, students can repeat the phenomenon and plan further investigation. As the result of the reflection, they may find new questions for the following investigation process [26].

\section{Methodology}

Chronology of the research is initiated with the identification of problems that exist in the field, literature review, quasi-experiment, the analysis of critical thinking skills test results, the interpretation of critical thinking skills test result, then the conclusion and recommendation. The complete chronology of the research can be seen in Figure 1.

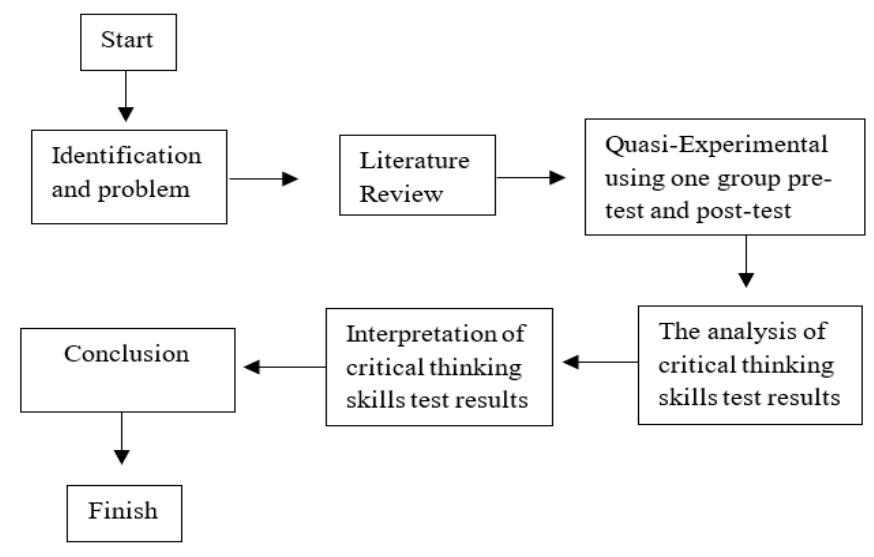

Fig. 1. Research flowchart

This research used Quasi-Experimental Model without control class to determine the effect of the use of Android-Based PhET Simulation on the critical thinking skills of students in MTs [27]. The research design used was one group pre-test and post-test design which was applied to 27 students of VIII class at MTs Alif Laam Miim Surabaya. The instrument that was used to find out students' critical thinking skills was a test of critical thinking skills which was prepared using the indicators of the skills to think critically by Facione (2015) [23]. Analysis of the data to find out whether there is an increase or not in the students' critical thinking skills used a paired t-test with formula $t=\frac{\bar{d}}{\frac{s}{\sqrt{n}}}[28]$ in which $\bar{d}$ states the average deviation, s states the standard deviation, and $\mathrm{n}$ denotes the number of samples; with the criteria for the test: reject $\mathrm{H} 0$ states that there is no difference in both mean of the pre-test and post-test, where $\mathrm{p}<.05$; besides the p-value, the $\mathrm{H} 0$ is accepted. Meanwhile, to see the level of improvement of students' critical thinking skills, this research used calculation of normalized gain $(\mathrm{N}-$ 
gain). Hake (1999) stated that $\mathrm{N}$-gain $=$ (post-test score - pre-test score) $/$ (maximum score - pre-test score), with the following criteria: $\mathrm{N}$-gain $>.70$ (high); .3 < N-gain < .7 (medium); and N-gain < .3 (low) [29].

The study was started by developing science learning tools such as: RPP (Lesson Plan), LKS (Student Worksheet), Teaching/Learning Materials and Test Instrument for critical thinking skills. Furthermore, the validity and reliability of the science learning tools are shown in Table 1.

Table 1. Validity and Reliability of RPP, LKS, Teaching Materials, and Critical Thinking Skills Test Instruments

\begin{tabular}{|l|c|l|c|l|}
\hline \multicolumn{1}{|c|}{ Learning Tools } & Validity & Category & Reliability $(\%)$ & Category \\
\hline RPP & 3.71 & Valid & 92.65 & reliable \\
\hline LKS & 3.67 & Valid & 91.67 & reliable \\
\hline Teaching Materials & 3.6 & Valid & 90 & reliable \\
\hline Test Instruments & 3.63 & Valid & 90.77 & reliable \\
\hline
\end{tabular}

Table 1 shows that the science learning tools which include: Lesson plans, worksheets, teaching materials and critical thinking skills test instruments are all categorized as valid and reliable. It means that these science learning tools are feasible and can be used in this research.

\section{Results and Discussion}

Android-assisted learning, especially in the Covid-19 situation, is an alternative solution for science learning. This study shows that science learning using Android-Based PhET Simulation is able to enhance the critical thinking skills of students. Before the learning was conducted, students first installed the PhET simulation application on the Google Play Store then accessed the PhET Simulation on their own Androids. The display of the Android-based PhET Simulation can be seen in Figure 2.

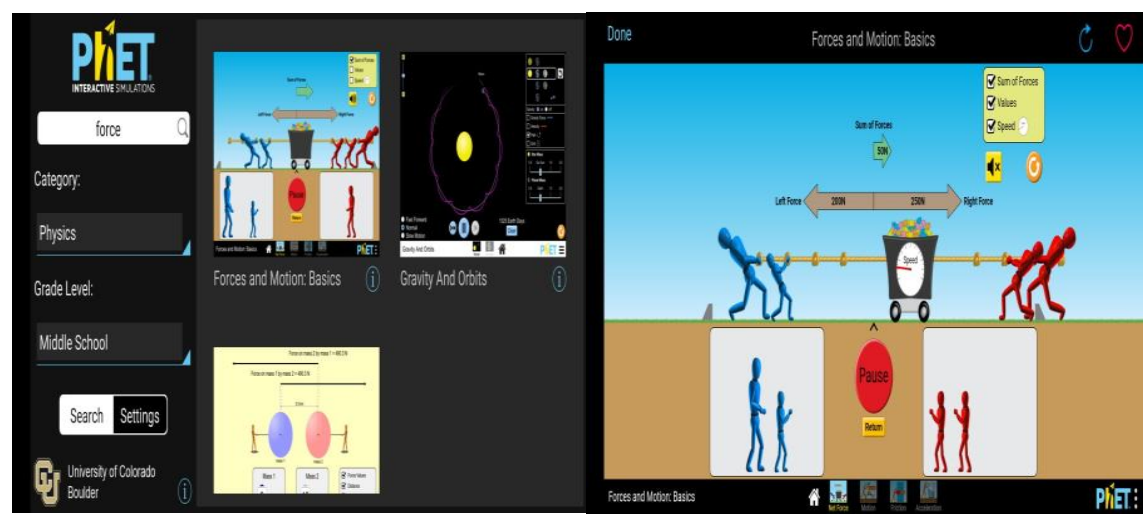

Fig. 2. Display of PhET Simulation on android [24] 
The scores of critical thinking skills of students in MTs were obtained by giving pretest and post-test of critical thinking skills. The pre-test, post-test, and $\mathrm{N}$-gain mean scores of MTs students' critical thinking skills can be seen in Figure 3.

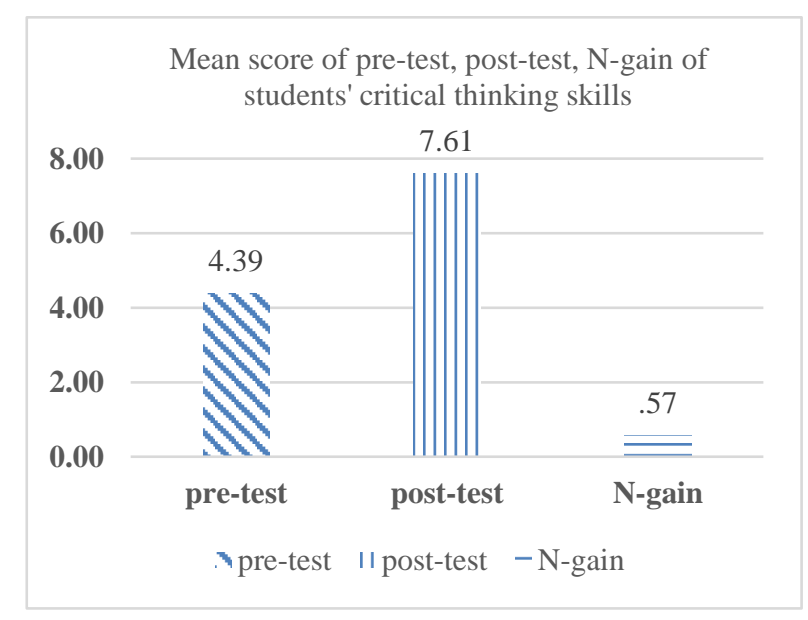

Fig. 3. Mean score of pre-test, post-test, and N-gain of students' critical thinking skills

A figure 3 shows that before the science learning using Android-based PhET Simulation was conducted, students had low mean score of critical thinking skills that is 4.39 from the range of score 0-10. After a given study, the mean score of students' critical thinking skills becomes quite high that is 7.61 , with a mean level of improvement (the mean of $\mathrm{N}$-gain) was .57 in medium category.

The increase in students' critical thinking skills was conducted by examining the mean scores similarity of pre-test and post-test using paired t-test, in which after $\mathrm{N}$ gain meets the requirements of normality test, or $\mathrm{N}$-gain derives from the population with normal distribution [30]. The paired T-test of mean scores of pre-test and post-test was done by using statistic software, SPSS version 20 and the results are presented in Table 2.

Table 2. The results of paired t- test of student critical thinking skills

\begin{tabular}{|l|c|c|c|c|c|c|}
\hline & N & Mean & Std. error of mean & t & df & p \\
\hline Pre-test -Post-test & 27 & -3.07 & .46 & -6.69 & 26 & $<.01$ \\
\hline
\end{tabular}
$* \mathrm{p}<.05$

Table 2 shows that the p-value is less than .05; It means that $\mathrm{H} 0$ which says that there is no difference between the mean of pre-test and post-test is rejected. Thus, there is a difference between the mean of pre-test and the mean of post-test. Since $t$ is negative, then the mean of the post-test is higher than the pre-test. In other words, the critical thinking skills score increased after a given learning by using Android-based PhET Simulation. 
Overall, the results of pres- test, post-test, and N-gain of VII class students of MTs Alif Laam Miim Surabaya are shown in Table 3.

Table 3. The results of pre-test, post-test, and N-gain value of each indicator

\begin{tabular}{|c|c|c|c|c|c|}
\hline Indicator & Activity & $\mathbf{N}$ & Mean & $\mathbf{N}$-gain & Criteria \\
\hline Interpretation & $\begin{array}{l}\text { Pre-test } \\
\text { Post-test }\end{array}$ & $\begin{array}{l}27 \\
27\end{array}$ & $\begin{array}{c}4.15 \\
9\end{array}$ & .83 & High \\
\hline Analysis & $\begin{array}{l}\text { Pre-test } \\
\text { Post-test }\end{array}$ & $\begin{array}{l}27 \\
27\end{array}$ & $\begin{array}{l}4.4 \\
6.6\end{array}$ & .39 & Medium \\
\hline Evaluation & $\begin{array}{l}\text { Pre-test } \\
\text { Post-test }\end{array}$ & $\begin{array}{l}27 \\
27\end{array}$ & $\begin{array}{c}4 \\
7.35 \\
\end{array}$ & .56 & Medium \\
\hline Inference & $\begin{array}{l}\text { Pre-test } \\
\text { Post-test }\end{array}$ & $\begin{array}{l}27 \\
27\end{array}$ & $\begin{array}{l}4.42 \\
7.22 \\
\end{array}$ & .5 & Medium \\
\hline Explanation & $\begin{array}{l}\text { Pre-test } \\
\text { Post-test }\end{array}$ & $\begin{array}{l}27 \\
27 \\
\end{array}$ & $\begin{array}{c}5 \\
7.3 \\
\end{array}$ & .46 & Medium \\
\hline $\begin{array}{l}\text { Self- regula- } \\
\text { tion }\end{array}$ & $\begin{array}{l}\text { Pre-test } \\
\text { Post-test }\end{array}$ & $\begin{array}{l}27 \\
27\end{array}$ & $\begin{array}{c}4.38 \\
8.2\end{array}$ & .68 & Medium \\
\hline \multicolumn{4}{|l|}{ Mean of N-gain } & .57 & Medium \\
\hline
\end{tabular}

Table 3 shows that the lowest score of the pre-test is reached on the indicator "evaluation" at 4 and the highest is on the indicator "explanation" which is 5, while the lowest score of the post-test is reached on indicator "analysis" at 6.6 and the highest is in the indicator "interpretation" which is 9 . In addition, it seems that the mean of the level of improvement (mean of $\mathrm{N}$-gain) is generated by .57 in the medium category.

Based on Figure 3, Table 2, and Table 3, it is proven that the use of Android-based PhET Simulation in science learning can improve students' critical thinking skills with an average $\mathrm{N}$-gain in the medium category. Students get the highest value of $\mathrm{N}$-gain in the indicator of "interpretation" in high category and get the lowest value of N-gain in the indicator of "analysis" in medium category. The lowest N-Gain occurred is expected due to the students' incompetence in analyzing the facts presented in observation in depth. It can be seen from the evidence included which was still superficial and majority of the reasons given were sourced from the internet. However, generally, the students' critical thinking skills are still quite high with an average $\mathrm{N}$-gain in the medium category. Thus, it can be said that the students' skills in analyzing problems still need to be improved further. The Skill to analyze is very closely related to skill to argue, while the skill to argue is the process undertaken by the students in the analysis of information related to specific topics in which the results are communicated to the other students. Therefore, before the students argue, first students should be able to analyze the facts or issues. The science learning activities that rely on delivering arguments have a direct impact on students' reasoning abilities improvement [31]. Students' skill in analyzing a problem is also greatly influenced by the skills to express reasons (reasoning). It is reinforced by the opinion that states that most students find it difficult to express the reasons, accompanied by evidence that supports the claim [32].

The use of Android-based PhET Simulation can improve the critical thinking skills of MTs students. "Interpretation" becomes an increase indicator with the highest Ngain score of .83. This data strengthens the result of the research which states that the use of PhET Simulation is not only able to improve critical thinking skills, but also to improve creative thinking skills [19]. In addition, the use of Android-based applications 
is proven to be effective in increasing student understanding in learning [33]. Non-faceto-face science learning can train students to compare various perspectives on scientific phenomena, analyze, and synthesize data to draw conclusion [34]. This opinion is also strengthened by the result of the research which concludes that scientific critical thinking skills can be improved through Edmodo-based blended learning [10, 35].

\section{Conclusion}

Based on the results of research and discussion, it can be concluded that science learning with the help of Android-based PhET Simulation can enhance MTs Students' critical thinking statistically significant, with the average $\mathrm{N}$-gain for about .57 , in the medium category; the highest $\mathrm{N}$-gain is achieved in the indicator of "interpretation", which is for about .83 and categorized as high and the lowest $\mathrm{N}$-gain is on indicator of "analysis", which is at .39 in medium category.

\section{Acknowledgment}

Authors would like to thank the Ministry of Education and Culture for the BPPDN scholarship program given to fund this research.

\section{$7 \quad$ References}

[1] Mahase, E. (2020). Coronavirus: covid-19 has killed more people than SARS and MERScombined, despite lower case fatality rate. The BMJ. 2 (1), 150-159. https://doi.org/10.11 36/bmj.m641

[2] Jeremy, B., Teresa, J., NuoXi \& Jonathan, S. (2013). Identifying the Most Important 21st Century Workforce Competencies: An Analysis of the Occupational Information Network Research Report. New York: ETS Researcher.

[3] Hsiung, W.Y. (2018). The use of e-resources and innovative technology in transforming traditional teaching in chemistry and its impact on learning chemistry. International Journal of Interactive Mobile Technologies, 12 (7), 86-96. https://doi.org/10.3991/ijim.v12i7.9 $\underline{666}$

[4] Papadakis, S., \& Kalogiannakis, M. (2019). Evaluating a course for teaching introductory programming with Scratchtopre-service kindergarten teachers. International Journal of Technology Enhanced Learning, 11(3), 231-246. https://doi.org/10.1504/ijtel.2019.100478

[5] Papadakis, S. (2020). Evaluating a game-development approach to teach introductory programming concepts in secondary education. International Journal of Technology Enhanced Learning, 12(2), 127-145. https://doi.org/10.1504/ijtel.2020.106282

[6] Papadakis, S. (2018). Evaluating pre-service teachers' acceptance of mobile devices with regards to their age and gender: a case study in Greece. International Journal of Mobile Learning and Organisation, 12(4), 336-352. https://doi.org/10.1504/ijmlo.2018.10013372

[7] Kalogiannakis, M., \& Papadakis, S. (2017). A proposal for teaching ScratchJr programming environment in preservice kindergarten teachers. In Proceedings of the 12th Conference of the European Science Education Research Association (ESERA) (pp. 21-25).

[8] Kalogiannakis, M., \& Papadakis, S. (2017). Pre-service kindergarten teacher's acceptance of "ScratchJr" as a tool for learning and teaching computational thinking and Science 
education. In Proceedings of the 12th Conference of the European Science Education Research Association (ESERA), Research, practice and collaboration in science education (pp. 31-37).

[9] Semerci, C. (2015). The influence in the critical thinking skills on the student achievement. Pakistan Journal of Social science, 3(4), 598-602.

[10] Wahyuni, S., Sanjaya, I.G.M., \& Jatmiko, B. (2019). Edmodo-based blended learning model as an alternative of science learning to motivate and improve junior high school students' scientific critical thinking skills. International Journal of Emerging Technologies in Learning, 14 (7), 98-110. https://doi.org/10.3991/ijet.v14i07.9980.

[11] Anwar, B. \& Mumthas. (2014). Taking triarchic teaching to classrooms: giving everybody a fair chance. International Journal of Advanced Research, 2(5), 455-458.

[12] Syafari. (2020). Developing analytic geometry module and cooperative learning models to improve critical thinking ability. Journal of Physics: Conf. Series. 1462, 012055. https:// doi.org/10.1088/1742-6596/1462/1/012055

[13] OECD. (2019). OECD programme for international student assessment 2018. OECD Publishing.

[14] Rutten, N., Van Joolingen, W. R., \& Van der Veen, J. T. (2012). The learning effects ofcomputer simulations in science education. Computers \& Education, 58(1), 136-153. https://doi.org/10.1016/j.compedu.2011.07.017

[15] Prima, E. C., Putri, A. R., \& Rustaman, N. (2018). Learning solar system using PhET simulation to improve students' understanding and motivation. Journal of Science Learning, 1(2), 60-70. https://doi.org/10.17509/jsl.v1i2.10239

[16] Chen, S. (2010). The view of scientific inquiry conveyed by simulation-based virtual laboratories. Computers \& education, 55(3), 1123-1130. https://doi.org/10.1016/j.compedu.2 $\underline{010.05 .009}$

[17] Ceberio, M., Almudí, J. M., \& Franco, Á. (2016). Design and application of interactive simulations in problem-solving in university-level physics education. Journal of Science. Education and Technology, 25(4), 590-609. https://doi.org/10.1007/s10956-016-9615-7.

[18] Wartono, W., Suyudi, A., \& Batlolona, J. R. (2018). Students' problem-solving skills ofphysics on the gas kinetic theory material. Journal of Education and Learning, 12(2),319324. https://doi.org/10.11591/edulearn.v12i2.8424

[19] Habibi, H., Jumadi, J., \& Mundilarto, M. (2020). PhET simulation as means to trigger the creative thinking skills of physics concepts. International Journal of Emerging Technologies in Learning, 15 (6), 166-172. https://doi.org/10.3991/ijet.v15i06.11319

[20] Popil, I. (2011). Promotion of critical thinking by using case studies as teaching method. Nurse Education Today, 31 (2011): 204-207. https://doi.org/10.1016/j.nedt.2010.06.002

[21] Hyytinen, H., Nissinen, K., Ursin, J., Toom, A., \& Lindblom-Yla"nne, S. (2015). Problematisingthe equivalence of the test results of performance-based critical thinking tests for undergraduate students. Studies in Educational Evaluation, 44, 1-8. https://doi.org/10.101 6/j.stueduc.2014.11.001

[22] Garrison, D. R., Anderson, T., \& Archer, W. (2011). Critical thinking, cognitive presence, and computer conferencing in distance education. American Journal of Distance Education, 15(1), 7-23. https://doi.org/10.1080/08923640109527071

[23] Facione, P.A. (2015). Critical Thinking: What it Is and Why It Counts. Insight Assessment. California: California Academic Press.

[24] University of Colorado. (2016). PhET Interactive Simulations. [Online]. Available: https:// phet.colorado.edu/. [Accessed 6 April 2020].

[25] Akinwale, O.B., Kehinde, L.O. (2017). Data compression for remote laboratories. International Journal of Interactive Mobile Technologies, 11(4), 95-113. https://doi.org/10.3991/ij im.v11i4.6743

[26] Joyce, B., Weil, M. \& Calhoun, E. (2015). Models of teaching, 9th edition. New York: Pearson Education Inc. 
[27] Arikunto, S. (2010). Research Procedure: A Practice Approach. Jakarta: Rineka Cipta.

[28] Sugiyono. (2018). Penelitian Kuantitatif, Kualitatif, dan R\&D [Quantitative, Qualitative, and R\&D Research]. Bandung: Penerbit Alfabeta.

[29] Setiani, R., Sanjaya, I. G. M., \& Jatmiko, B. (2019). ARICESA as an alternative learning model to improve learning motivation and understanding of student concepts. International Journal of Instruction, 12(2), 383-398. https://doi.org/10.29333/iji.2019.12225a

[30] Jatmiko, B. et al. (2018). The comparison of OR-IPA teaching model and problem-based learning model effectiveness to improve critical thinking skills of pre-service physics. Journal of Baltic Science Education, 17 (2), 300-319.

[31] Hasyim, F. (2018). Mengukur kemampuan berpikir analitis dan keterampilan proses sains mahasiswa calon guru fisika STKIP Al Hikmah Surabaya [Measuring pre-service physics teachers' analytical thinking ability and science process skills of STKIP Al Hikmah Surabaya]. Jurnal Pendidikan IPA Veteran, 2(1), 80-89. https://doi.org/10.31331/jipva.v2i1.591

[32] Lazarou, D., Sutherland, R., Erduran, S. (2016). Argumentation in science education as a systemic activity: An activity-theoretical perspective. International Journal of Educational Research, 79, 150-199. http://doi.org/10.1016/j.ijer.2016.07.008

[33] Wijaya, K.I. et al. (2019). The effectiveness of mobile learning-based android in learning english vocabularies. International Journal of Interactive Mobile Technologies, 13 (12), 226235. https://doi.org/10.3991/ijim.v13i12.11167

[34] Vogel, B. et al. (2010). Integrating mobile, web and sensory technologies to support inquirybased science learning, Presented at the 6th IEEE International Conference on Wireless, Mobile, and Ubiquitous Technologies in Education. https://doi.org/10.1109/wmu te. 2010.41

[35] Wahyuni, S., Erman, Sudikan, S. Y., Jatmiko, B. (2020). Edmodo-Based Interactive Teaching Materials as an Alternative Media for Science Learning to Improve Critical Thinking Skills of Junior High School Students. International Journal of Interactive Mobile Technologies, 14(9), 166-181. https://doi.org/10.3991/ijim.v14i09.13041

\section{Authors}

Faiz Hasyim is now a doctoral student at Science Education Study Program, Postgraduate Program, Universitas Negeri Surabaya [The State University of Surabaya], Surabaya, Indonesia. He currently serves as a lecturer at STKIP Al-Hikmah, Surabaya, Indonesia.

Tjipto Prastowo is a senior lecturer at Physics Department, Universitas Negeri Surabaya [The State University of Surabaya], Surabaya, Indonesia and joins Science Education Study Program, Postgraduate Program, The State University of Surabaya, Surabaya, Indonesia.

Budi Jatmiko is a professor at Physics Department, Universitas Negeri Surabaya [The State University of Surabaya], Surabaya, Indonesia and joins as a senior lecturer at Science Education Study Program, Postgraduate Program, The State University of Surabaya, Surabaya, Indonesia. His research interests cover a wide range of research topics in the fields of science and physics education. He is also appointed as a Rector at Universitas Dinamika [The University of Dinamika], a private university located in Surabaya, Indonesia. While supporting the two universities, he currently serves as Editor in Chief of Journal of Physics Research and Its Application, a growing peer-reviewed journal managed by Physics Department, The State University of Surabaya, accessed at https://journal.unesa.ac.id/index. php/ipfa.

Article submitted 2020-05-23. Resubmitted 2020-09-09. Final acceptance 2020-09-09. Final version published as submitted by the authors. 